\title{
Editorial: Inequalities, Financialization, Technology: Sometimes the Nearest Exit is Behind You
}

\author{
Stefano Prato ${ }^{1} \cdot$ Flora Sonkin $^{1}$
}

Published online: 27 September 2019

(c) Society for International Development 2019

Development turned 60. After six decades of continued publishing, this 61 st volume explores the future of development policy by also reflecting on past development decades, which the Journal untiringly witnessed, followed and contributed to.

In the early development decades, global development challenges were approached by the international community as stemming from extreme poverty. Poverty was then treated as the starting point of the analysis as well as the main problem to be tackled through development interventions. However, this mainstream narrative focused on poverty reduction was only looking at the end of the story, turning a blind eye to the dynamics of wealth accumulation in so-called developed economies and underplaying the legacy of colonialism, slavery and resource extraction in the so-called developing countries. The focus on poverty as an almost exclusively 'catch-up' challenge often overlooked the vicious relations between poverty and prosperity. Without confronting the historical conditions and unfairness of global capitalism at the root of the problem, false solutions to minimize poverty only ended up reinforcing it. ${ }^{1}$ What is finally becoming more broadly accepted is that poverty does not stand in a vacuum separate from wealth; it is but one of many symptoms of historically rooted and still growing global inequalities.

In recent years, a significant increase of disparities within and between countries in both the Global North and the Global South has finally put inequalities under the spotlight

The initial part of the article is taken from the framing chapter of the 'Spotlight Report on Financial Justice: Understanding global inequalities to overcome financial injustice' (provisional title, forthcoming), authored by Flora Sonkin, Stefano Prato and Matti Kohonen.

Stefano Prato

stefanop@ sidint.org

Flora Sonkin

fsonkin@sidint.org

1 Society for International Development (SID), Rome, Italy in international development debates. ${ }^{2}$ Especially since the 2008 global financial crisis, deep inequalities across economic, social, political and intergenerational domains are no longer confined to low-income or developing countries. Quite the opposite: deeper gaps between rich and poor, between groups who influence policymaking and those marginalized by it, between those who can access quality education, healthcare, food and other basic goods and services and those who cannot afford them are increasing all over the world. Some staggering examples are the fact that food insecurity is on the rise for 4 years in a row in both high-income and low-income countries, with over 820 million people suffering from hunger, ${ }^{3}$ while approximately 1.6 billion people lack adequate housing. ${ }^{4}$ Meanwhile, the richest $1 \%$ owns over $47 \%$ of total global wealth, ${ }^{5}$ and financial power concentration is making the rich get richer nearly everywhere. ${ }^{6}$

While our current global economic system and its governance structures reinforce a vicious cycle of inequalities by keeping political and financial power in few hands, this gloomy situation also offers an opportunity for convergence of diverse movements and struggles under a common agenda. A strong feeling of unfairness about our society's deeply unequal condition is no longer restricted to those considered economically marginalized, but it is actually shared by the majority of working people around the world. And this feeling has been approaching a tipping point. Social movements such as Occupy Wall Street_and its subsequent

\footnotetext{
1 https://www.theguardian.com/global-development-professionalsnetwork/2017/jan/14/aid-in-reverse-how-poor-countries-develop-richcountries?CMP =share_btn_fb\&fbclid=IwAR3Hevd03vf3dZwQPt4pjdV-5GHZomNG8bdmruV9fAS9yQd_aHyKfkznB0.

${ }^{2}$ https://sustainabledevelopment.un.org/sdg10.

${ }^{3}$ http://www.fao.org/publications/sofi/en/.

${ }^{4}$ https://unhabitat.org/up-for-slum-dwellers-transforming-a-billionlives-campaign-unveiled-in-europe/.

5 https://www.credit-suisse.com/about-us/en/reports-research/globa l-wealth-report.html.

${ }^{6}$ https://www.theguardian.com/business/2019/jan/21/world-26-riche st-people-own-as-much-as-poorest-50-per-cent-oxfam-report; https:// inequality.org/facts/global-inequality/.
} 
protests in 951 cities in 82 countries in both Global North and South-, the indignados/15M in Spain, Nuit Debout in Paris, and so many other recent popular uprisings around the world have shown people's power to unite against inequality, finance capitalism and anti-democratic governance. The growing climate movement and its youth-led Fridays for Future strikes are also key to exposing the multidimensionality of the inequalities question. Organized youth have been taking to the streets worldwide to sound the alarm on the unacceptable unfairness of climate change and environmental degradation, as the climate crisis not only disproportionately affects groups according to their geographic location and economic power, but also across generations. Those responsible for over-consuming our limited planetary resources in the present are not equally burdened by the future consequences of their actions.

\section{Inequalities: Understanding Power Concentration While Providing Normative Guidance}

The inequalities framework offers a remarkable transformational potential if compared to the traditional poverty approach. Not only does it provide greater descriptive accuracy (by demystifying averages and exposing correlations between development challenges and social groups) and analytical capacity (by unveiling the relations between poverty and prosperity), but it also offers a powerful 'rule of thumb' in normative terms: tackling inequalities in their multidimensional character-social, political, economic, spatial and intergenerational-can become a sort of guiding star in a complex world, an overarching goal to advance sustainable development and address the root causes of marginalization. This means that challenging the drivers that continue to widen disparities and confronting the political economies that facilitate the capture of ethical, normative and fiscal interventions in favour of the economic and political elites is amongst the most urgent policy priorities to advance socioeconomic transformation. The analysis of multidimensional inequalities highlights how some social groups and communities are consistently found at the lower end of any development outcome distribution, exposing structures of power within societies of which socio-economic disparities are one of many symptoms. A political economy assessment will therefore invariably conclude that inequalities are primarily governance challenges, unfolding the need to combine socio-economic interventions with robust processes aimed at democratizing the existing concentration of economic and political powers.

The conceptual framework of inequalities also offers interesting analytical insights into some of the powerful economic dynamics that have shaped, and continue shaping, the current pattern of economic globalization under the aegis of liberalization at any cost: corporate concentration, financialization and what Evgeny Morozov has brilliantly defined as 'techno-solutionism', i.e. the idea that given the right code, algorithms and robots, technology can solve all of mankind's problems (Morozov 2014).

\section{Corporate Concentration, a Breeding Ground for Unequal and Unfair Development}

Corporate concentration is not a new phenomenon, given that oligopolies, and in some cases, duopolies characterize many market segments. However, this process has now reached unimaginable proportions, often reaching entire economies. As captured by a 2019 Barclays publication related to the US, corporate concentration increased in the US market as a whole and within most market sectors. Meanwhile, US business dynamism, labour's share of income and capital growth have all decreased since $2000 .{ }^{7}$ Creeping consolidation of many industries in recent years also led corporate profits to reach record highs relative to GDP. ${ }^{8}$

Market power concentration is taking whole new shapes and repercussions, as uncovered by a new antitrust investigation over big tech companies, namely Facebook and Google, for their undue influence in public communication and political debate. ${ }^{9}$ New spins in the dynamics of corporate concentration and consolidation are equally evident in the interplay between food, health, finance and technology. As exposed by excellent recent reports published by the ETC Group ${ }^{10}$ :

The historic division between (a) agrochemical formulators and fertilizer manufacturers (b) grain traders and plant breeders, and (c) grocery retailers and tractor manufacturers no longer applies. While stockbrokers and antitrust monitors have been watching [several mega] mergers (...), the convergence of powerful

\footnotetext{
${ }^{7}$ Barclays, Increased corporate concentration and the influence of market power, Impact Series N.5, 2019 https://www.investmentbank. barclays.com/content/dam/barclaysmicrosites/ibpublic/documents/ our-insights/MarketPower/Barclays-ImpactSeries5-MarketPower_ final_2.4MB.pdf (last accessed on 12 September 2019).

8 The Economist, Corporate concentration: The creep of consolidation across America's corporate landscape, March 24, 2016. https:// www.economist.com/graphic-detail/2016/03/24/corporate-concentrat ion (last accessed on 20 September 2019).

${ }^{9}$ Steve Lohr, The New York Times, Google Antitrust Investigation Outlined by State Attorneys General, September 9, 2019 https://www. nytimes.com/2019/09/09/technology/google-antitrust-investigation. html (last accessed on 20 September 2019).

${ }^{10}$ Pat Mooney, ETG Group, Blocking the Chain, October 2018 http://www.etcgroup.org/sites/www.etcgroup.org/files/files/blockingth echain_english_web.pdf (last accessed on 12 September 2019).
} 
new digital technologies - computer data and DNA - means that more profound changes and even greater monopolies are on their way. Within the machinations of global markets, our food security is entangled in an omnibus data platform. (...) This new Big Data platform invites - almost requires - cross-sectoral convergence, and those who control the platform can literally regroup the industrial landscape.

It is also thanks to corporate concentration and market consolidation that the growing expansion of the global finance industry - or financialization - and techno-solutionism are allowed to breed, as both require standardized large-scale applications to fully unfold their expansionary, profit-seeking and self-replicating dynamics.

\section{Financialization: Driver of Inequalities and Obstacle to Transformation}

According to one of the most widely used definitions by Gerald A. Epstein, 'Financialization refers to the increasing importance of financial markets, financial motives, financial institutions, and financial elites in the operation of the economy and its governing institutions, both at the national and international levels. ${ }^{11}$ The implications of financialization are pervasive and perverse: (1) it generates distance between players, strengthening the role of intermediaries and shifting economic proceedings away from the local/real economy, contributing to economies of rent as well as shrinking wages and economic margins of peasants and other smaller-scale local economic actors; (2) it challenges national sovereignty as legitimate public policy spaces and decisions may become hostage of (often foreign) investors' perceptions, preferences and decisions, contributing to opaqueness in decision making and favouring policy capture and political economies; (3) it changes the nature of development interventions, as investment decisions may be more concerned with scale, user-fees and short-term financial returns, rather than equitydriven structural socio-economic transformations; and (4) it siphons resources away from productive purposes as most financial flows are now invested and re-invested in shortterm financial transactions within financial markets themselves. The current inclinations for large-scale infrastructural projects that facilitate resource extraction from Southern, often African, countries, to attract foreign investors, while neglecting smaller-scale infrastructures that could strengthen industrialization, economic diversification and local/regional

\footnotetext{
11 Gerald Epstein, Financialization, Rentier Interests, and Central Bank Policy, December, 2001, then revised in June 2002 http://www. peri.umass.edu/fileadmin/pdf/financial/fin_Epstein.pdf (last accessed on 12 September 2019).
}

markets, is a perfect exemplification of the vicious policy cycles promoted by financialization.

As argued by Jomo Kwame Sundaram and Michael Lim Mah Hui, foreign investments are primarily interested in capturing more rents and their contribution may be highly asynchronous with countries' desirable sustainable development strategies:

(...), they demand more favourable terms and conditions, thus changing national financial systems. Successfully attracting transnational finance thus limits 'emerging market' economies' 'policy space' to develop their economies. (...) The enabling environment to attract capital inflows typically allows them to circumvent regulations and other institutional constraints. Deepening national capital markets by relying on transnational finance typically involves 'subordinate' or 'dependent' financialization. (...) This typically requires modifying national financial systems to better serve transnational finance and transitioning from traditional banking to financial asset markets. Thus, developing countries, that open their capital accounts or encourage transnational portfolio investments, become especially vulnerable. ${ }^{12}$

\section{Techno-Solutionism and Unequal Development}

But financialization is only one side of the coin. We also live in an era of technology euphoria, one that may also contribute to collective hypnosis. There is virtually no development challenge that does not have a wave of techno-solutions and significant constituencies of techno-optimists.

While technology is certainly critical to address many development challenges, it is not a panacea and may often involve several locks-in in terms of model and scale of production, intellectual property regimes that may further promote the concentration of wealth and economic power, ownership and control of information, with significant implications in terms of privacy, civil liberties and democratic accountability, among others. The so-called Fourth Industrial Revolution, for instance, seen by many of its proponents as a new opportunity for economic growth, increased efficiency and productivity, is also likely to largely replace

\footnotetext{
12 Jomo Kwame Sundaram and Michael Lim Mah Hui, Developing Economies' Subordinate Financialization, published on IPS News on 17 September 2019 http://ipsnews.net/2019/09/developing-econo mies-subordinate-financialization (last accessed on 17 September 2019).
} 
humans by robots in many sectors. ${ }^{13}$ As automation substitutes labour across the entire economy, the displacement of workers by machines exacerbates the gap between returns to capital and returns to labour, deepening inequalities while enriching the owners of intellectual and physical capital: corporate elites. It is therefore essential to have proper mechanisms for independent and democratic assessment of the full implications of technological options, including the risk for unexpected techno-disruptions and possible spill-overs within unintended domains, and tackle the challenges of technology governance, recognizing that technology justice is an integral part of development justice.

The technology divide needs to be addressed not only by ensuring access to adequate development technologies, but by tackling increasing corporate control over technologies that threaten privacy, marginalize community innovations and encourage new patterns of dependence. This also means de-coupling the notion of innovation from modern technologies and recognize the critical role and contribution of diverse knowledge systems to the pursuit of sustainable development, including indigenous knowledge systems as well as informal technologies and innovations that have allowed communities to cope with climate, environmental and resource scarcity challenges. Technology, at least in conventional terms, is therefore not the solution to all our problems and, sometimes, technology-hope may generate spaces of comfort where we underplay the real extent of the production and behavioural transformations that are really needed. Technology allows some to think that they can have their cake and eat it too.

Hence the challenge to formulate development policies that do not fall into the possible traps of finance and technology. A feat particularly challenging in a policy turf where these two ingredients are constantly referred to as gamechangers for every problem on the horizon, without questioning they actually fall very short in tackling the multiple dimensions of inequalities.

\section{Multistakolderism and Shifting Governance: Corporate Capture of Democratic Decision-making}

However, addressing these policy challenges is becoming even more complicated due to the progressive strengthening of a new approach to governance defined as 'multistakeholderism'. Under the guise of more democratic participation in decision-making, the proliferation of high-level multi-stakeholder platforms is a new expression of how corporate power

\footnotetext{
13 https://unu.edu/publications/articles/is-technological-innovation -making-society-more-unequal.html.
}

concentration is reaching new realms of political influence, further threatening the possibility of structural shifts in global governance to redistribute power and reduce global inequalities. As nicely stated by Harris Gleckman when commenting on the latest partnership agreement between the United Nations and the World Economic Forum:

The latest institutional foray is a World Economic Forum-UN partnership agreement. Under this arrangement, senior UN leaders are invited at national, regional and international levels to interact with forum members, many of whom are actually causing the global problems that the UN system is tasked to fix, such as climate change. These developments are part of a new global governance approach, one in which a team of corporate executives, leaders of civil society organizations, officials from governments and the UN system, academics and other players take on the governance of a specific international challenge. In the economic, social and environmental fields, this governance arrangement is called multistakeholderism, as each new global decision-maker is said to represent a "stakeholder" in an issue. In practice, these governance arrangements can have a role equal to or greater than the one held by the intergovernmental body officially assigned to address a universal problem. ${ }^{14}$

Multistakeholder governance creates parallel governance structures-and in some cases actually completely supersedes existing ones-where corporate interests co-decide, with 'equal' power, with somehow legitimate governmental representatives, blurring lines between public and private interests, shifting attention away from rights-holders in favour of an ill-defined notion of stakeholders, and lockingin governance arrangements that will effectively ossify the normative control of economic elites and mega-corporate over all crucial aspects of (development) policy.

\section{Real Transformation May Need a Step Back Rather than a Fast Forward}

In turn, to advance a socio-economic transformation agenda requires a profound reshaping of economic thinking, strategizing and modelling, taking into consideration the intersections of inequalities along the spheres of gender, race, and class. To address power imbalances and prevent development solutions from being captured by corporate power

\footnotetext{
${ }^{14}$ Harris Gleckman, They Call It Multistakeholderism. Where Does That Leave the UN? TNI, 2019 https://www.tni.org/en/article/theycall-it-multistakeholderism-where-does-that-leave-the-un (last visited 19 September 2019).
} 
through financialization and technocratic solutions, inequalities must be addressed from the boardrooms of multinational corporations, to national and regional governance, and to the halls of the United Nations. At micro level, there is a need for a new business model grounded in a novel theory of the firm, in terms of economic theory, regulatory framework and management practice, placing economic activities within a systemic understanding of ecological cycles, social dynamics and gendered relations. An unsustainable and patriarchal production model is in fact at the core of many of the challenges to which the Sustainable Development Goals seek to address (Prato et al. 2018). At meso level, it is essential to redirect economic development strategies away from the chimera of integration in the global economy, favouring instead the strengthening of domestic and regional economies, based on sustainable industrialization, economic diversification and territorial markets. Agrobiodiverse local food systems are both the cornerstone of economic sovereignty as well as the systems most harmed by the hegemonic and hegemonizing corporate-led global food system. But breaking the vicious circles of resource-extractive economies and commodity dependence requires, at macro level, the democratization of global economic governance, challenging the current global division of labour and tackling the systemic obstacles to economic transformation generated by current monetary, financial and trade regimes. New global institutions as well as profound reforms of existing ones are urgently necessary to create the policy and fiscal space that developing countries require to advance the quest for greater economic democracy within and between countries as the critical pillar to tackle structural multidimensional inequalities. The incestuous political economies that dominate the nexus between finance and technology and development policy can only generate impediments to such a transformative-maybe utopian for some-agenda.

What's the option? Without a doubt, take a step back. Resisting financialization and actively promoting de-financialization, pursuing innovations and transformations that do not hard-wire modern technologies in all our economic and social systems, reclaiming legitimate rights-based democratic spaces.

As many travellers are often told, sometimes the nearest emergency exist is behind you.

\section{References}

Morozov, Evgeny. 2014. Save Everything, Click Here: Technology, Solutionism, and the Urge to Fix Problems that Don't Exist (English Edition), Penguin.

Prato et al. 2018. Policies that strengthen the nexus between food, health, ecology, livelihoods and identities, Spotlight Report on Sustainable Development, https://www.2030spotlight.org/en/ book/1730/chapter/2-policies-strengthen-nexus-between-foodhealth-ecology-livelihoods-and. Accessed 19 September 2019.

Publisher's Note Springer Nature remains neutral with regard to jurisdictional claims in published maps and institutional affiliations. 